\title{
Invisible Restriction: Franchising Development in Kazakhstan
}

\author{
Raissa Kaziyeva \\ Department of Management, Narxoz University, Kazakhstan
}

Copyright $\mathrm{C} 2016$ by authors, all rights reserved. Authors agree that this article remains permanently open access under the terms of the Creative Commons Attribution License 4.0 International License

\begin{abstract}
The purpose of the article is to identify the so-called "invisible factors" hindering the development of franchising in Kazakhstan. The author's studies since the early 2000s, business training, seminars, consulting services for existing and potential entrepreneurs indicate that neither the laws nor the special government programs to support small and medium-sized businesses in the country, have become the decisive force so far, which would give the necessary dynamics to the process. The main attention is paid to the identification of differences between the expectations of both Kazakh franchisees and franchisors, as well as how differently both sides are currently viewing accountability to each other, what they are willing to offer each other, how they see their rights and obligations. Current legislation of the Republic of Kazakhstan in the field of franchising, unfortunately, does not eliminate the discrepancies in views and visions of the parties in franchise relationship. This article attempts to give practical implications for franchising development in Kazakhstan that will raise the effectiveness and enhance the credibility of franchising business through preliminary screening of subjective assumptions regarding franchising advantages and benefits, using a cross-comparative analysis, as well as provide recommendation to add addenda and clarifications to the agreement as necessary.
\end{abstract}

Keywords Entrepreneurship, Franchising Agreement, Expectations, Obligations, Negotitations, Franchisee, Franshisor, Kazakhstan

JEL Classification Number: L26

\section{Introduction}

Franchising is present in nearly all sectors of small and medium-sized business in Kazakhstan. Particularly, it is prominent in retail industry, services industry, and various production spheres. However, the role of franchising in the development of small and medium-sized enterprises (SMEs) remains less significant, which often leads to inadequate understanding and groundless expectations of franchising business model.

Today, many global brands such as World Class, Pizza Hut, ZARA, Coca-Cola, Adidas, are operating in Kazakhstan among many other brands. In March 2016 the first McDonald's restaurant opened in the capital of Kazakhstan Astana. Opening of the second restaurant of the company is also expected for 2016, and in the next five years, about 15 more are expected to launch. Similarly, there also exist many low budget franchises in the industries as retail, services, artisan, media, internet technologies, etc.

However, in anticipation of the effects of the deepening economic crisis, the business activity declines. The relationship between franchisors and owners of shopping centers has worsened. After a sharp weakening of the national currency as a result of the new monetary policy of the Central Bank of the country, a number of franchised outlets have closed due to the increased cost of goods received to sell and lease of retail space.

Nevertheless, the Annual Conference and Exhibition Kazfranch-2015 showed that the country's pool of Kazakhstan franchise leaders is formed. The number of franchises is growing by an average of $10-20 \%$ per year [1]. The market potential despite the crisis, remains high.

\section{Critical Review of Franchising Development in Kazakhstan}

According to the experts, it is important to know whether there exists a positive impact on the franchise development on Kazakhstan's economy. It is also necessary to identify the main factors hindering the promotion of franchising in Kazakhstan [2].

Among the obvious factors influencing the development of the franchise is the effective state support in the field of intellectual property protection laws.

However, as international experience shows, first franchising develops, and then the laws and special support programs appear. A striking example is China, where the law 
of the franchise came into force in 1997, with the first franchise point emerging in the late ' $80 \mathrm{~s}$.

But, of course, we should not underestimate the role of legislation and state support in the development of franchising. Due to the Law on franchising among other things, in particular, paragraph on the mandatory disclosure presale information by the franchisor, the number of fraudulent franchise schemes in the United States has decreased dramatically. Due to the participation of the state, program "Franchising for veterans and pensioners," is developing successfully. This program allows seniors to use the pension fund to finance their own franchise.

It is interesting to note the state program to stimulate China's franchise, in which there is a clause on mandatory participation of Chinese entrepreneurs in all of franchising projects with foreign participation. With this program in China, tens of thousands of franchised outlets have been created with the participation of local entrepreneurs. As a vivid example of the result of this program, we can note a joint program of "Kodak" Company and the Bank of China, as a result of the introduction of which thousands of businesses have been established throughout the country under the "KEX photo express» trademark.

Interesting is the experience of Malaysia, on the development of franchising. Given the low financial capacity of local businesses, many proposals of foreign franchisors remained unfulfilled. Malaysian Ministry of Enterprise, together with the Office of the Franchising Development has developed a program to identify potential franchisees, as well as - the mechanism of consultative and financial support for these franchisees themselves. As a result of this initiative, a large number of franchise businesses have appeared in the country.

As can be seen from the above, the state support of franchising is very important in the development of the franchising market.

It is in this light, the most important for the development of the domestic franchising is to create a program to support entrepreneurship "Roadmap-2020" [3].

At the same time, the dynamics of the formation and development of the domestic franchising remains low.

In comparison to 2002 , only 2 domestic franchises were registered in the country [4]; in 2013, 14 domestic franchises have been registered, 4 of which operate in foreign countries [5]. Even though there has recently been a number of domestic franchise forming in the domestic market, foreign franchises still dominate this market completely [6]. Russia ranks first in this regard, the second popular are American franchises. Russian franchises operating in Kazakhstan do not require much adaptation. This is attributed to the similarity in consumer behavior and languages. Moreover, there are some other factors preventing more presence of foreign franchises within domestic market, which are as follows:

- poor activity of Kazakhstani businessmen in the international franchising market,

- under-population,
- relatively sparse consumer's market.

As practice shows, the large number of domestic (home-based) franchisors, as well as those foreign franchisors, who have already gained their own experience of operation in the local market is possessing the main criterion of success for development of franchise relationships in any other countries. This conclusion is drawn from the inherent value of the business model implemented by a franchisor. For both existing and prospective franchisees, such value, in the first place, is attributable to a franchisor's experience in operating in a particular local market include awareness of the market's specific features, consumer preferences, availability of customer base, developed system of delivering the resources, and system of finished commodity (services), etc. Even the most well-known international brands also try to "gain" some "additional values" associated with the local specificity through a period of promoting their business models in a foreign market.

It should be emphasized that domestic franchising in any country is a symbol of national pride; its development is an indicator of maturity of business and economy.

According to forecasting by the experts, the number of foreign brands will reach 550 by 2022 , provided that Kazakhstani entrepreneurs are granted franchises, and the number of Kazakhstani franchisors will triple, $15 \%$ of which will enter the foreign markets [5]. Unfortunately, even the forecasted growth in number of domestic franchises is not encouraging. This can be attributed to particular risks associated with the implementation methods of foreign franchising systems in Kazakhstan. Some of the aforementioned risks are described as follows:

1. The rapid replacement of domestic manufacturing by foreign businesses is the prospect of a worst case scenario (taking into consideration the projected expansion of the Customs Union, establishment of Eurasian Economic Area, and Kazakhstan's joining of WTO). As analyzed in a SWOT matrix, these are substantial threats are exposing weaknesses of the current business competitiveness in Kazakhstan. If this challenge is not addressed appropriately, then the said risks will result in further degradation of domestic entrepreneurship.

2. Selling a franchise, as well as any other goods and services, involves promotion of certain amenities that would satisfy the desires of the customers. Nowadays, in the times of cosmopolitanism and globalization of a modern customer, the culture and history of a country and its nations, as well as their religious views predetermine the specific patterns and behavior of consumption. Unfamiliarity, negligence thereof, with such specifics often leads to failure of promotion. As often seen, foreign franchises, without any particular adaptation and experience in a local market, are faced with these kinds of problems. Hence, this could provide a relative advantage of domestic businesses.

The complications arising from implementing "twists and turns" methods of goods and services promotion are quite 
serious and real. As practice shows, even local entrepreneurs sometimes fail to distinguish a right context from a wrong one, which causes controversial situations. A recent case occurred in Actobe, Kazakhstan, involving a sales campaign of a vodka brand, "Bayterek," in which an inscription on the bottle reads, "Power of Allah is ample for all of us." The information center reported that the vodka was being sold all over the Republic and it was being supplied to Semey town by the DENIJO Company, which in turn, had purchased the products from the GEOM Company registered in Actobe town [7]. The GEOM Company management later sent a letter of apology to Supreme Mufti of Kazakhstan, providing an explanation for the situation that the label had been designed by another Russian company, and that the designers had mixed up the word "Allah," written in Arabic, with Kazakh national ornament.

With the controversy aside, it should be noted that foreign franchisors who promote their business models in the local market plays a positive role in stimulating the interest of Kazakhstani entrepreneurs in franchising. The foreign franchisors can gain the necessary experience in the domestic market, as well as increase the values (Kazakhstani content) of their franchises, while providing a valuable example in building up effective business models and successful promotional campaigns. This would be an appropriate response to address the foreign franchising challenges in Kazakhstan; these challenges should be considered as motivation for national development and "lessons learned."

There are currently some noteworthy trends and franchising development forecasts in Kazakhstan. The multi-brand operators who have two or more franchise licenses in their portfolio will play a major role in the development of domestic franchising sector. Primarily, Kazakhstani franchise purchasers are interested in retail industry, particularly in the segment of trendy clothes and footwear. Food services industry is also rapidly developing, e.g. street food, fast food, cafes, restaurants, etc.

Goods and services for children segment is also developing in Kazakhstan. In addition, the number of Kazakhstani franchises is increasing in the foreign markets. They are fashion designers, restaurateurs, and business concepts in the areas of finance and logistics. Social franchising is growing into a business segment in Kazakhstan. The number of Kazakhstani online users approximates 10 million; more than 3 million people use social networks [8]. Thus, social networks can easily be used as the main brand promoting tool.

The dynamics in development of franchising relations in Kazakhstan is not quite positive yet. Often inadequate understanding and groundless expectations related to franchising are typical among businessmen in Kazakhstan. This reduces the effectiveness, leads to disappointment, and cripples the concept of franchising as well. In fact, the process of signing franchise agreements is difficult; however, this phase can serve as a valuable opportunity to overcome misconception of the parties and to eliminate unrealistic expectations of automatic success. Thus, this article is dedicated to addressing this issue. The growth dynamics and franchise development forecasting indices are listed in Table 1 .

In 2015, 495 franchise systems were presented in Kazakhstan.

The annual turnover of the enterprises working in Kazakhstan on franchising, is approaching \$ 3 billion [9].

Forum, conferences, seminars and trainings held by the Franchising Union Consortium with the assistance of its partners, including Entrepreneurship Development Fund "DAMU" in Kazakhstan, solicit some great interest of entrepreneurs in franchising business. However, active promotion of franchising ideas in Kazakhstan is not always received with correct perception and adequate understanding, on the part of entrepreneurs, with respect to the essence of the business structure.

According to the research data, stability of any socioeconomic system lies not only in the formalization of its structure and in quantity (and not even in quality) of its components, but also in the nature and characteristics of the internal relations between them. Variability, elasticity of such relations, "latent relations," as well as adequacy to events, in which the external business environment must face, can make the system, even a franchising business, sufficiently stable even through recessionary periods.

Franchising systems carry a great energy-information meaning as they integrate direct transfer of traditions, knowledge, and technology together. Such socioeconomic systems of various formats are basically "practical communities," having the following distinctive features: (1) joint initiative; (2) general set of established practices, through formalized and non-formalized rules of behavior and knowledge.

Table 1. Growth dynamics and forecast of franchising development in Kazakhstan

\begin{tabular}{|c|c|c|c|}
\hline Index & 2010 & 2013 & $\begin{array}{c}2022 \\
\text { forecast }\end{array}$ \\
\hline $\begin{array}{l}\text { Franchising share in the structure of small and medium business (in terms of a number of small and medium business } \\
\text { entities) }\end{array}$ & $3 \%$ & $3.5 \%$ & $15 \%$ \\
\hline Number of foreign franchises & 220 & 340 & 550 \\
\hline Number of domestic franchises (based on conclusion of franchising agreements) & 9 & 14 & 40 \\
\hline Number of domestic franchises represented abroad & 2 & 4 & 15 \\
\hline
\end{tabular}


Differences between expectations and responsibilities (subjective assumptions): a practical implication

Experts from many different countries note that problems related to franchise relationships can arise from differing expectations of a franchisor and franchisee. Among them are some recommendations to conduct research franchise conflicts in order to develop a better understanding of the root causes and to identify methods to minimize them, which may include, for example, providing a Pre-Entry Franchise Education Program [10]. The franchising code of conduct (Australian Competition \& Consumer Commission -ACCC) was reviewed and updated in 2015. Since this update there is a requirement for both Franchisees and Franchisors to act in "Good Faith". Good faith requires that parties exercise their power reasonably and not arbitrarily or for some irrelevant purpose [11].

Participation in the work of numerous business forums, held both in Kazakhstan and abroad, personal experience, conversations, and meetings with business people at seminar/training allow us to draw the following conclusion of realistic principal importance-a misconception in relation to the essence of franchising causes misunderstanding, which provokes further disagreements between participants of franchising agreements. If such disagreements are not resolved in due time, they may escalate into oppositions and conflicts.

Some inconsistencies are frequently revealed on the waiting lists of potential franchisors and franchisees during seminars and trainings, held for business people in Kazakhstan. Some of the expectations from both parties are described in Table 2.

Some expectations are based on misconception or on the fact that participants interpret the wordings with different meanings and perceptions. However, some of them should be used for improvement of the business system, and as additions and refinements for the franchise agreement, for instance, how to avoid cut-throat competition between franchise system members. This is a task for the franchisor and a requirement to prevent competition within the network is useless if the problem of "how to do it in practice" is not solved first.

Many items from the list of franchisor's expectations, regarding a successful franchise, depend primarily on how a business model is executed, and subsequently, on ethics and integrity of the franchisee. For example, item 2 from the list of franchisor's expectations, which is controlled level of sales (proceeds), depends on a control mechanism over the level of sales that must be circumspect, perspicuous, and transparent enough for a simple and practical implementation; otherwise, it would indicates a serious defectiveness of a business model and its financial soundness.

According to the experts, one of the most prominent mistakes made by franchisors is their failure to constantly monitor the development of an established franchising system, after selling a franchise. In this case, the terms "monitor" and "control" not only mean the supervision of a franchisee, but also the correction, depending on a market situation: and (1) activities of a franchisor (its policy), or and (2) activities of a franchisee. In other words, the purpose of monitoring to be carried out by a franchisor is an adequate response, by all the participants (both parties) of franchising relations, to market changes.

Moreover, the franchisor must remember that consumers perceive each enterprise, a franchisee, as a part or a link in a common chain-they are united under a single trademark. And, if at least one of the franchisees experiences mishaps in its activities, this would negatively affect the reputation of the whole franchising system.

Table 2. Expectations of potential franchisors and franchisees

\begin{tabular}{|c|c|c|}
\hline & Franchisor's expectations & Franchisee's expectations \\
\hline 1. & Increase in profits due to an established network & 1. Purchase of a worked out scheme of money making checked by a Franchiser \\
\hline 2. & Controlled level of sales (proceeds) of individual & and its acting franchisees \\
\hline & franchisees in general & 2. Reliability of information regarding Franchiser's business results (it is \\
\hline 3. & $\begin{array}{l}\text { Brand name growth recognizability } \\
\text { Promotion of reputation }\end{array}$ & $\begin{array}{l}\text { necessary for a franchisee that a Franchiser shows its results and positive results } \\
\text { of its franchisees) }\end{array}$ \\
\hline 5. & $\begin{array}{l}\text { Business development (quicker change and } \\
\text { adequate change of business in accordance with }\end{array}$ & $\begin{array}{l}\text { 3. To a sufficient extent freedom and financial independency (an opportunity to } \\
\text { work for itself) }\end{array}$ \\
\hline & $\begin{array}{l}\text { changing market requirements and conditions) (on } \\
\text { the principle "Two heads are better than one") }\end{array}$ & $\begin{array}{l}\text { 4. A level of yield is higher than estimated profit at the independent start and } \\
\text { conduct of business }\end{array}$ \\
\hline 6. & Efficiency and discipline of a franchisee ("contract & 5. Less risks (financial, production, etc.) \\
\hline & 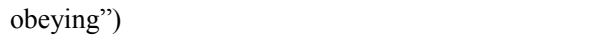 & Avoidance cut-throat competition within the franchise network \\
\hline 7. & Honesty on the part of a franchisee & Personnel training \\
\hline & A franchisee will not participate in competitive & 8. Provision of technology, sales methods (and other know-how) \\
\hline & activity & Saving in advertising expenses and other methods of goods/services promotion \\
\hline
\end{tabular}


Table 3. Obligations of the Parties to franchising relations

\begin{tabular}{|c|c|}
\hline Franchisor is obliged to: & Franchisee is obliged to: \\
\hline $\begin{array}{l}\text { 1. Pass franchisee technical and commercial } \\
\text { documentation and submit other information } \\
\text { necessary for the implementation of franchisee rights } \\
\text { granted to him under the contract of complex business } \\
\text { license how to conduct business and ensure its } \\
\text { support } \\
\text { 2. Conduct personnel training (training/additional } \\
\text { training) } \\
\text { 3. Disclose commercial information required for conduct } \\
\text { of business (know-how, a right to use inventions, etc., } \\
\text { commercial experience) }\end{array}$ & $\begin{array}{l}\text { 4. Fulfill requirements and conditions of the contract } \\
\text { 5. Refrain from disclosing commercial information } \\
\text { 6. Not to participate in the activities of competitors of the franchisor } \\
\text { 7. Inform the customers is most evident manner that franchisee is using the firm } \\
\text { name, trade mark, service mark or other means of identification on the basis } \\
\text { of the franchise agreement } \\
\text { 8. Ensure quality standards for goods and services } \\
\text { 9. Provide a franchisor with required and reliable information (franchisee is } \\
\text { required to allow the franchisor to its production area to provide it with the } \\
\text { necessary documents and assist in obtaining the information necessary for } \\
\text { exercising control over the correct use of granted exclusive rights) } \\
\text { 10. Timely to make payments for the use of exclusive rights }\end{array}$ \\
\hline
\end{tabular}

Brand recognizability and positive reputation of a franchise (Table 2, items 3 and 4) do not appear automatically when creating a franchising network. If a mechanism for controlling operational, production, and process activities of a franchisee is not elaborately established, then negative consequences occur. In such a case, control over operational activities must be equally effective regardless of geographic remoteness from a franchisor's base of operation. Some time ago, V.Dovgan, a pioneer of the Russian national franchising complained about the failure of "Doka-Pizza" project because of dishonesty of franchisees that violated the production technology agreement [12]. V.Dovgan stated that, in fact, pizza franchising was an excellent idea to earn money. But, why did it fail? Sixteen pizzerias were established in Tolyatti, by the side of offices, but only two of them were making quality pizza in accordance with a recipe.

Domestic and international experience in the field of entrepreneurial business shows that the "weak" links of a business model provoke deviation in participants' behavior.

Franchisee's expectations regarding relatively smaller business risks (Table 2, item 5), in case of entry into franchising relations, are frequently exaggerated. Business reproduction in the form of franchising is not "cloning." Authentic domestic features, such as legislation, consumer preference, etc., require the participants to have a keen sense of business in risk assessment, and franchise development to target these specific features. Franchisee's misconception regarding this concept needs to be "rectified" at once; otherwise, it may lead to a business failure.

\section{Obligations and Expectations of the Parties}

Experts also emphasize the need to improve legislation on franchising in Kazakhstan [2]. The fact of the matter is we see a significant difference between the expectations (Table 2) and the obligations (Table 3), between the two parties, which are set by the law "on package entrepreneurial license (franchising) [13].

One of the problematic points of contractual relations is a guarantee of confidentiality of trade secrets, which includes intellectual property of a franchisor. What is an intellectual property of a franchisor? Franchisor's "know-how" is identified and protected as confidential, primarily, in the sphere of an organizational management mechanism, yet still providing functionality and continuous development of a franchising system as a whole. The way a franchisor applies such a technique, method and tool to support stability, effectiveness and protection of the system is through its "package" and the essential attractiveness of the system for new franchisees.

In accordance with provisions of the Civil Code of the Republic of Kazakhstan [14] and the law of the Republic of Kazakhstan "on package entrepreneurial license (franchising)" [13], a right to use a trade name and other types of intellectual property of a franchisor shall be transferred to a franchisee. Such transfer shall apply to information that are both (1) protected by patents for inventions, useful models and industrial patterns, and (2) know-how protected within the framework of commercial secret protection.

In this case, there is a contradiction between the franchise agreement and the law governing the confidentiality of the trade secrets. A crucial component in a successful franchise system is the "know- how," which if transferred on the basis of a right of use, will lose its status as a "know-how", and any access, even lawful access, to the entities by any party other than participants of contractual relations, is prohibited. In practice, according to a franchising contract, a franchisee is prohibited from disclosing such information to the public, but this must happen anyway. Does this mean that a franchisor/owner is divested of a right to ensure confidentiality of a certain part of information, the "know-how," and must take measures to protect it? The answer is "no" and conversely, this right must remain active. In practice, the "know-how" without further development and enrichment quickly loses its value. Franchisee's motivation for long-term business partnership and its attractiveness are based on constant expansion and development of franchisor's experience and skills. Another thing is that "know-how" protected by a franchisor must not restrict the franchisee's direct business activities. 
There should always be transparency between the participants in order to maintain the effectiveness of the entire franchise system.

Kazakhstani franchisors often believe that they can simply satisfy the requirement to develop its franchise, with necessary package of documents and guidance for franchisees, through professional consultants or specialized companies. An example is, Kuralai Nurkadilova, the founder of the fashion house brand "Kuralai" who advises franchisors that the whole package of documents, e.g. brand book, manuals, are quite simple to create [15]. Nowadays, there are many professional consulting services for the establishment of franchises in the market. In fact, experts from Russia and Ukraine have great experience in this field.

However, success is not guaranteed for a new business start-up. Indeed, all business models must adapt to adequately follow market changes, and must always be attractive to the franchisee-network members. Franchisors, themselves, must understand that changes are constantly needed and directly participate in their development and testing. Reproduction by local entrepreneurs of efficient foreign franchising models, even with well-adopted ones, still does not exhibit the same potential possessed by the original model development.

Entrepreneurship Development Fund "DAMU," in Kazakhstan, provides training under the business advisor project, oriented to support new entrepreneurs. We strong encourage participation in these teaching programs and practical consulting services focusing on franchising.

There is another serious inconsistency in the nature of franchising - that is the competition within the franchise network itself. On the one hand, a franchisee serves as a partner in the development of the system as a whole. On the other hand, they deliver products and services to the market through the same local market as the others. How could a mechanism, of interaction between franchisees within the system, be created in order to provide an effective cooperation and partnership? This is a mission of a franchisor, whereby its organizational management skills in the field of brand capitalization will be challenged.

A cross-comparative analysis (cross-screening) has been carried out in order to determine the correspondence of typical expectations and obligations (subjective assumptions) among the parties of franchising relations in Kazakhstani business. The cross-screening results of the franchisor's expectations versus the franchisee's obligations and vice versa, are shown in Table 4 and 5, respectively.

Many subjective assumptions (expectations from both sides) are based on misconception; if they are realized automatically, they would work against the entry into contractual relations like an invisible restrictive force. Some assumptions remain "open" ("Not applicable") in the Tables below. In this case, "open" expectations are a response indicating that both parties (a franchisor and a franchisee) should make their own efforts.

It is also necessary to turn our attention toward clarifying of individual provisions of franchising agreements, so that both parties may accept the terms with the same understanding and expectation. We recommend a screening process for franchisor's and franchisee's interests and expectations prior to any agreement signing. We must also account for the life cycle of any enterprise, and that at different stage the expectations and interests of the participants may change. Change can also cause crises and conflicts and to prevent possible conflicts between the participants, all parties conduct some form of expectation evaluation at each stage throughout the life cycle of the franchise company.

During harsh economic conditions, franchising relations may inevitably become aggravated. It is necessary to emphasize that the risks of inequitable conduct of participants of franchising relations are typical for the whole international business community. During the "start-up" age of franchising in Kazakhstan, the most common problem is how franchisors can secure their business against unfair infringement of franchisees and how to minimize these risks. According to Daft, during this first "entrepreneurial stage" of organizational life cycle, control is based on the owner's personal supervision, or the need for Leadership [16]. Moreover, provisions with clear directions typically lead to business growth. Thus, the next step would be finding a mechanism to maintain appropriate degree of franchisee autonomy and creativity, or the need for delegation with control, while adapting to consumer needs and volatile market conditions.

Table 4. Cross-screening: franchisor's expectations and franchisee's obligations

\begin{tabular}{|ll|ll|}
\hline \multicolumn{2}{|c|}{ Franchisor's expectations } & \multicolumn{2}{|c|}{ Franchisee is obliged to: } \\
\hline 1. & Increase in profit due to an established network & 1. & Not applicable \\
\hline 2. & $\begin{array}{l}\text { A controlled level of sales (proceeds) of individual franchisees and the } \\
\text { network in general }\end{array}$ & 2. & $\begin{array}{l}\text { Provide a Franchiser with required and reliable } \\
\text { information }\end{array}$ \\
\hline 3. & Growth of name (brand) recognizability & 3. & Not applicable \\
\hline 4. & Promotion of reputation & 4. & Not applicable \\
\hline 5. & Compliance with quality standards & 5. & Ensure quality standards for goods and services; \\
\hline $6 . \quad \begin{array}{l}\text { Business development (quicker change and adequate change of business in } \\
\text { compliance with changing market requirements and conditions) }\end{array}$ & $6 . \quad$ Not applicable \\
\hline 7. & Efficiency and discipline of a franchisee ("contract obeying") & 7. & Fulfill requirements and conditions of the contract \\
\hline 8. & A franchisee shall keep commercial secrecy & 8. & Refrain from disclosing commercial information \\
\hline 9. & A franchisee will not participate in competitive activity & 9. & $\begin{array}{l}\text { Not to participate in the activities of competitors of the } \\
\text { franchisor }\end{array}$ \\
\hline Source: Author & \multicolumn{2}{l}{} \\
\hline
\end{tabular}


Table 5. Cross-screening: franchisee's expectations and franchisor's obligations

\begin{tabular}{|c|c|}
\hline Franchise's expectations & Franchisor is obliged to \\
\hline $\begin{array}{c}\text { Purchase of a worked out scheme of money making checked by a } \\
\text { Franchiser and its acting Franchisees }\end{array}$ & Train how to conduct business and provide business support \\
\hline $\begin{array}{l}\text { Reliability of information regarding Franchisor's business results (it is } \\
\text { necessary for a franchisee that a Franchisor shows its results and positive } \\
\text { results of its franchisees) }\end{array}$ & Not applicable \\
\hline $\begin{array}{l}\text { To a sufficient extent freedom and financial independency, auto (an } \\
\text { opportunity to work for itself) }\end{array}$ & Not applicable \\
\hline $\begin{array}{l}\text { A level of yield is higher than estimated profit at the independent start } \\
\text { and conduct of business }\end{array}$ & Not applicable \\
\hline Less risks (financial, production, etc.) & Not applicable \\
\hline Personnel training & Personnel training \\
\hline Use of a famous brand & A right to use a trade name, trade mark and service mark \\
\hline $\begin{array}{l}\text { Receipt of technology, sales methods (and other know-how) from a } \\
\text { Franchiser }\end{array}$ & $\begin{array}{l}\text { Commercial information required for conduct of business (know-how, a } \\
\text { right to use inventions etc., commercial experience) }\end{array}$ \\
\hline $\begin{array}{l}\text { Saving in advertising expenses and other methods of goods/services } \\
\text { promotion }\end{array}$ & $\begin{array}{l}\text { Advertising (it should be clarified in the contract whether for additional } \\
\text { payment or not?) }\end{array}$ \\
\hline Effective sales & $\begin{array}{l}\text { Marketing research (it should be clarified in the contract whether for } \\
\text { additional payment or not?) }\end{array}$ \\
\hline Production cost reduction & Not applicable \\
\hline
\end{tabular}

\section{Conclusions}

A crucial indicator for a successful franchising business and striving development is a dynamic formation and promotion of domestic, or home-based, franchise systems. This is also confirmed by international practices. However, statistics show that the share of Kazakh-established franchises in the mass-promoted domestic market is not significant.

Successful franchising, of course, are those where processes are bottom-up, initiated by the participants themselves. It is for these initiatives, other things being equal, government support should be provided. Unfortunately, those projects are supported, which are initiated from above and implemented on the principle of «top-down». Such projects are usually, nonparticipative and inviable. In addition, of particular interest is the question of what criteria these projects (out of «top-down») are selected by. However, this is a subject of another discussion.

We cannot hope for a simple, automatic transfer of the quantity of foreign franchises, implemented by Kazakhstani entrepreneurs, into so called "quality establishment and growth of domestic franchises." There are additional requirement in the forms of interactive teaching programs, developing a "taste" of entrepreneurs to establish their own "long- lasting" and "challenging" franchises, and not causing franchisee to escape their nets.

In Kazakhstan, there were many cases of refusal from the current practice of franchising. The reasons included: improper and unethical conduct of the franchisor or franchisee, the franchisee optional ratio to the standards and rules of the franchise system, the lack of control by the franchisor of its franchisees. As a result, the level of service and quality of products significantly reduced, which led to a decrease in franchise brand reputation and loss of customers. Many precedents unsuccessful franchise - it is the fault not only of the franchisee, but of the franchisor as well.

The franchisor does not always care about the franchisee's profits. In the international franchise history, there are many cases of not completely ethical practice of franchising. "Franchises phony" were created for quick profits of the franchisor, but led to the bankruptcy of the franchisee.

Based on the polls conducted among local potential and existing franchisors and franchisees, we have identified and considered unrealistic, misperceived expectations and responsibilities from both sides of the franchising relationship. They are like an invisible force that restricts franchising development.

Our recommendation to collaborate and negotiate, using methods such as cross-screening on the participants' subjective assumptions and make appropriate adjustments, early during the application process and also in all subsequent stages of the life cycle of the franchise company.

There is a considerable difference between expectations (wishes) of participants of the franchising relations and obligations of the parties, which are specified in the legislation of Kazakhstan. Certainly, as noted in the Civil Code of the Republic of Kazakhstan that, by the contract, other duties of the franchisor and the franchisee can also be included [14]. However, an absence of some essentially important points in the obligations of the parties, for instance, avoidance of competition within the franchise network, in legislative documents, in our opinion, would demand special considerations.

Timely negotiations of invisible barriers, in the process of franchising development in Kazakhstan, will allow the participants to maximize their positive effects. Indeed, accumulation of innovative energy, in the business 
environment, and its promotion are carried out due to the reproduction process. Transfer of organizational management technology does not constrain, but stimulates innovative activities of a franchisee. This is a basis for displacement of equilibrium and entrance into a sustainable economic growth.

\section{REFERENCES}

[1] Capital. Centre of business information. Among the domestic brands do not have a franchise more million dollars. Retrieved April 14, 2014 from https://kapital.kz/expert/47775 /sredi-otechestvennyh-brendov-net-franshizy-dorozhe-million a-dollarov.html

[2] Duissembayev, A. Franchising as an Example of an Innovative Business Development. Materials of International Forum. Franchising-trend of business, education and innovation. Almaty: Economika, 2013

[3] Business Territory. Prospects of franchising development in the framework of Roadmap 2020. Retrieved April 14, 2014 from http://business.gov.kz/ru/franchising/franchising-develo pment-prospects.php

[4] Issledovanie "Franchajzing v Kazakhstane", 2011 [Review "Investigation: Franchising Development in Kazakhstan"] Retrieved March 24, 2014 from http://www.franchexpo.kz/ru/ pr-novosti-stati/public/13-issledovaniefranchajzing-v-kazakhstane

[5] Vestnik Soyuza franchayzinga. [Vestnik of Franchising Union Consortium]. 1, 33. Retrieved March 24, 2014 from http://www.franchising-asia.kz/images/vestnik/2014_1_vestni $\mathrm{k}$ _franchising.pdf

[6] Kaziyeva, R., Duissembayev, A. A., \& Kisikov, B. Franchising. A Methodological Guide for Businesses of Kazakhstan. DAMU Entrepreneurship Development Fund, Almaty, 2011

[7] News (2012). In Kazakhstan Vodka with the Mention of Allah on the Label Was Withdrawn from the Sale. Retrieved March 24, 2014 from http://lenta.ru/news/2012/04/05

[8] Novyie vozmojnosti biznesa [New opportunities of business], 2013. Retrieved April 14, 2014 from http://forbes.kz/finances /markets/novyie_vozmojnosti_biznesa

[9] Business Territory. Statistics of Kazakhstani franchising.
Retrieved April 14, 2016 from http://business.gov.kz/ru/franc hising/kazakhstan-franchising-statistics.php

[10] Towards Conflict Resolution. Australian Survey, 2009. Retrieved March 24, 2014 from http://www.franchise.edu.au/ home/research/franchise-conflict

[11] Elizabeth Gillam. I wish I had known what "Good Faith" is. Asia-Pacific Centre for Franchising Excellence. Retrieved April 14, 2016 fromhttps://www.franchise.edu.au/home/topic s/franchise-business-management-topics/i-wish-i-had-knownwhat-good-faith-is/_nocache?dm_i=2Y5A,6W6Z,1OZP9O,L ISA, 1

[12] Dovgan, V. Franchising-the Way to Business Expansion. Moscow: Nauka, 1994

[13] On Package Entrepreneurial License (Franchising). The Law of the Republic of Kazakhstan, 2002. Retrieved April 14, 2016 from http://www.adilet.zan.kz/rus/docs/Z020000330

[14] Civil Code of the Republic of Kazakhstan (1999). (Special part) with changes and additions as of March 07, 2014. Retrieved April 14, 2016 from http://online.zakon.kz/Document/?doc_i $\mathrm{d}=1013880 \#$ sub $\mathrm{id}=8980000$

[15] Kazakhstan Franchise-Who Are Ready? Tips from the Kazakh Experts for Beginning Franchisors, 2014. Retrieved March 24, 2014 from http://idea-lab.kz/2014/01/22

[16] Daft, R. L. Organization Theory and Design (9th ed.). Thomson South-Western,2007

[17] APCFE (2014). Managing Franchise Problems. Asia-Pacific Centre for Franchising Excellence. Retrieved March 24, 2014 from http://www.franchise.edu.au/home/topics/how-to-franch ise-topics/managing-franchise-problems

[18] Ibragimova, L. (2013). Official Greetings. Official Catalogue. Materials of the 7th Central Asian International Exhibition of Franchising. ITE Group, Almaty.

[19] Kissikov, B. (2011). Franchising in Kazakhstan. Almaty: Igilic, 85-89.

[20] RIFDK (2011). Review "Investigation: Franchising Development in Kazakhstan." Retrieved March 02, 2014 from http://www.franchexpo.kz/ru/pr-novosti-stati/public/13issledovanie-franchajzing-v-kazakhstane

[21] FVK (2011). Issledovanie "Franchajzing v Kazakhstane" [Review "Investigation: Franchising Development in Kazakhstan"]

[22] Retrieved March 24, 2014 from http://www.franchexpo.kz/ru/ pr-novosti-stati/public/13-issledovanie-franchajzing-vkazakhstane 